\title{
Music and Organ School of the Association of Education in Ostrava-Mariánské Hory / Masaryk Institute of Music and Singing in 1907-1939
}

\author{
Jiří Kusák / jiri.kusak@osu.cz
}

Centre for Research into Culture and Identity of the Region, Department of Music Education, Faculty of Education, University of Ostrava, CZ

\begin{abstract}
The study deals with the educational and artistic activities of the Music and Organ School of the Association of Education in Ostrava-Mariánské Hory / Masaryk Institute of Music and Singing from 1907 to 1939. The school was one of the first institutions established under the auspices of societies or associations in Ostrava and during the period under study its organ and music education departments were of fundamental importance, with a large number of artistic events taking place. The Music and Organ School of the Association of Education in Ostrava-Mariánské Hory / Masaryk Institute of Music and Singing can be considered a key institution in the history of music education not only in the region, but also in a broader context.
\end{abstract}

\section{Key words}

Music and Organ School of the Association of Education in Ostrava-Mariánské Hory, Masaryk Institute of Music and Singing, Ostrava, music education, music school system, organ department, music education department, Eduard Marhula, František Míta Hradil, Leoš Janáček, Josef Bohuslav Foerster. 


\section{Introduction}

Ostrava, a predominantly industrial city without a significant previous musical tradition, became an important centre in the 20th century, with a very good quality of musical culture. What can be considered an important determinant is the changing political, ethnic and social situation, with the imperial monarchy being replaced by the democracy of the interwar Czechoslovak Republic in the period in question. ${ }^{1}$ In the context of developmental changes in Ostrava's music education, it is important to point out that music education activities in Ostrava must also be monitored, analysed and critically evaluated in relation to the musical culture of the period that was simultaneously developing in Ostrava. From today's perspective, the objective value of manifestations of regional music education can be identified as a certain problem, because "regional phenomena must not be overestimated, but they should not be underestimated either (which often happens in supraregional historiography, sometimes also due to insufficient knowledge of the region and its events)". ${ }^{2}$

\section{Music schools and institutes in Ostrava}

Music education in music schools and institutes in Ostrava can be traced back to the early 1890s, when the first private music schools with a wide range of educational and artistic activities were established. ${ }^{3}$ Two school institutions should be mentioned - the Academic Music School and the Institute of Music Education (Musik-Bildungs-Anstalt). If the Academic Music School was of great importance for the Czech population, an analogy can also be found for the Germans in Ostrava, who had the opportunity to study at the Institute of Music Education (Musik-Bildungs-Anstalt) from 1893. This institute was connected with Arthur Könnemann ${ }^{4}$ and, compared to the Academic Music School, whose activities were

1 STEINMETZ, Karel - MAZUREK, Jan - KUSÁK, Jiří et al. Ostrava hudebni. Vývoj hudebni kultury jednoho města v poslednich 160 letech. 1st ed. Ostrava: Ostravská univerzita v Ostravě, Pedagogická fakulta, 2014, pp. 6, 9-10.

2 Ibid., p. 9.

3 The study is based on the manuscript of the habilitation thesis KUSÁK, Jiří. Ostrava hudebněvýchovná. Hudebni výchova, odborná hudebni výchova, hudebni výchova v učitelské př́pravě, hudebni lidovýchovné a popularizačni aktivity v Ostravě od 90. let 19. století do roku 1945. Ústí nad Labem, 2017, 302 pages. Habilitation Thesis. Univerzita Jana Evangelisty Purkyně v Ústí nad Labem, Pedagogická fakulta.

4 The personality of Arthur Könnemann and the activities of the Institute of Music Education (Musik-Bildungs-Anstalt) are documented by the German press of that time: Ostrauer Zeitung (1893-1897, 1899, 1902-1903, 1905-1907, 1923, 1925-1926, 1931, 1935). There is also a useful publication by Könnemann on instrument playing: KÖNNEMANN, Arthur. Rascher zum Ziel. Anleitung zur höheren technischen Ausbildung der Hand auf mechanischem Wege. Moravská Ostrava, 1892. More information can be found in KUSÁK, Jiř́i. Didactic-Analytical and Content-Related Reflection on the Works by Ostrava Teachers Rudolf Kadleček and Arthur Könnemann in the Context of Specialized Music Education in the Early 20th Century. In Horizonty umenia 6. Banská Bystrica: Akadémia umení v Banskej Bystrici, Fakulta múzických umení, 2019, pp. 230-240. 
limited to the creative life of Rudolf Kadleček (died in 1917) ${ }^{5}$, it successfully influenced the forms of Ostrava's music education for a longer period of time, until the 1930s (1931).

From the point of view of the history of regional music education, both Kadleček's Academic Music School and Könnemann's Institute of Music Education (Musik-Bildungs-Anstalt $)^{6}$ can be seen as very important educational institutions, because they influenced the later establishment of society and union music schools in Ostrava: the Music and Organ School of the Association of Education in Ostrava-Mariánské Hory (1907) / later the Masaryk Institute of Music and Singing; the Music School of the Záboj Society in Slezská Ostrava (1908) / later the Rund Music School of the Záboj Singing Society, and the Music School of the Association of Metalworkers in Ostrava-Vítkovice (1922) / later the Dr. Leoš Janáček Music School.

\section{On the development of the Music and Organ School of the Association of Education in Ostrava-Mariánské Hory / Masaryk Institute of Music and Singing (1907-1939)}

Based on a decree of the Provincial School Board of 22 August 1907, the Music and Organ School of the Association of Education in Ostrava-Mariánské Hory opened its doors on 15 October $1907 . .^{7}$ An important role in the establishment of the school was played by the Association of Education in Ostrava-Mariánské Hory and Eduard Marhula, because “[...] he was the soul of the idea, and the Association of Education made it come true" ${ }^{8}$ Both the statutes and the musical syllabus of the Music and Organ School of the Association of Education were adopted, and Eduard Marhula, "as the future school principal, was invited to work on its

5 The personality of Rudolf Kadleček and the activities of the Academic Music School are documented by the Czech press of that time: Opauský týdennik (1895-1896), Ostravský dennik (1910, 1914, 1916-1917), Ostravský kraj (1910, 1912-1917), Poledni ostravský denik (1929). There are also Kadleček's articles in the journal Dalibor from the beginning of the 20th century, as well as publications on instrument playing and music education: KADLEČEK, Rudolf. Theorie hmatniku houslového. Př́ručni knižka ku vyučováni počátkưm hry na houslich pro učitele $i$ žáka. Moravská Ostrava, 1904. KADLEČEK, Rudolf. O výchově hudební. Popularisace myšlenky o správné výchově hudebni. Moravská Ostrava, 1905.

6 The excellent quality level of Könnemann's Institute of Music Education (Musik-Bildungs-Anstalt) in education and art is evidenced by Anna Wüstner's extensive positive reviews in Ostrauer Zeitung from the 1920s.

7 This study deals with the educational and artistic activities of the Music and Organ School of the Association of Education in Ostrava-Mariánské Hory / Masaryk Institute of Music and Singing in the period from its establishment in 1907 to 1939 (the beginning of the Protectorate period). We consider the Music and Organ School of the Association of Education in Ostrava-Mariánské Hory / Masaryk Institute of Music and Singing to be a key educational institution in the Ostrava area. In addition to the period in question, i.e. 1907-1939, the Masaryk Institute of Music and Singing also carried out interesting activities during the Protectorate of Bohemia and Moravia (1939-1945). For more details on the music education in music schools and institutes in Ostrava during the Protectorate, see KUSÁK, Jiří. Odborná hudební výchova v Ostravě v období Protektorátu Čechy a Morava. In Janáckiana 2016. Sbornik z 33. ročniku muzikologické konference Janáckiana 2016. Ostrava: Ostravská univerzita, Pedagogická fakulta, 2017, pp. 253-262.

8 Archiv města Ostravy (AMO), 40. jubilejni výročni zpráva Masarykova městského ústavu hudby a zpěvu s právem veřejnosti v Ostravě. Ostrava, 1947, p. 12, call number A 2651/1, inventory number 3130. 
organisation together with the local school principals". ${ }^{9}$ The annual report also adds that, at the next meeting, Marhula informed the Board of Trustees about the official permission to open the school (based on the telegraphic message by the provincial inspector Mnuk about the Provincial School Board's decision), the promotion of the opening of the Mariánské Hory school was entrusted to the Ostrava press, and private music teachers were invited to work at the school. ${ }^{10}$ "Preparatory work for its opening was started immediately. Posters and local magazines announced the enrolment. [...] 28 pupils enrolled before classes began."11

The establishment of the Music and Organ School of the Association of Education can be interpreted as a significant achievement in the field of education, because it soon became "a model for many newly emerging music schools", ${ }^{12}$ as well as in Ostrava's musical life. "The establishment of the music school of the Association of Education in Ostrava-Mariánské Hory was not only a direct consequence of Leoš Janáček's penetrating teaching influence on his pupils, but also a far-sighted and meritorious work of considerable cultural and artistic educational content. In his ideas, Marhula conceived a widely branched professional music institute, putting all his efforts into this thought, which he also passed on to the teaching staff at his school." 13

Classes took place in the building of the boys' primary school in Mariánské Hory. In the 1907/1908 school year, in addition to Eduard Marhula, the teaching staff consisted of six teachers: F. Krčová (piano), B. Krč (violin), J. Kupka (violin), A. Schneider (piano), V. Wiedermann (violin) and A. Zamazal (liturgics). In the following 1908/1909 school year, due to the increasing number of pupils, classes took place in the lower secondary school building, with only four rooms for both teaching and school management. From the time the school opened, there was considerable interest especially in the organ department, in which pupils from the Ostrava region, Silesia, Lachia, Moravian Wallachia and East Moravia were educated. ${ }^{14}$

The Mariánské Hory organ school offered a two-year study programme, but after an inspection visit by Leoš Janáček, provincial inspector for music education, on 14 June $1911^{15}$ a decision was made to extend the length of study to four years, beginning from the 1913/1914 school year. ${ }^{16}$ F. M. Hradil mentions that Janáček positively assessed especially the organ school's concept and the results of the teachers' teaching activities. Marhula was

9 AMO, XX. jubilejni výroční zpráva 1907-1927. Moravská Ostrava, 1927, p. 42, call number A-2650, inventory number 3129.

10 Ibid., pp. 42-43.

11 Ibid., p. 43.

12 HRADIL, František Míta. Hudebníci a pěvci v kraji Leoše Janáčka. Paměti a dokumentace. 1st ed. Ostrava: Profil, 1981, p. 101.

13 HRADIL, František Míta. Hudební tradice v kraji Leoše Janáčka. K 60. výročí trvání lidové školy umění v Ostravě 1. In 60 let lidové školy v Ostravě. Ostrava, 1967, p. 10.

14 HRADIL, Hudebnici a pěvci v kraji Leoše Janáčka, op. cit., p. 102. KUSÁK, Jiří. Z dějin regionální hudební výchovy v Ostravě v letech 1890-1918. Odborná hudební výchova. Hudebni výchova. 2016, Vol. 24, No. 1-2, p. 6.

15 Janáček had visited the school as an inspector in 1910. HRADIL, Hudebníci a pěvci v kraji Leoše Janáčka, op. cit., p. 102, and HRADIL, Hudební tradice v kraji Leoše Janáčka, op. cit., p. 11.

16 AMO, XX. jubilejní výroční zpráva 1907-1927, op. cit., pp. 9-10; see also KUSÁK, Z dějin regionální hudební výchovy v Ostravě v letech 1890-1918, op. cit., p. 6, and MAZUREK, Jan. K dějinám Hudební a varhanické školy Matice školské v Ostravě-Mariánských Horách (1907-1935). Hudebni nástroje. 1995, No. 4, p. 245. 
keen to find high-quality teachers, which was not an easy task. Hradil states that graduates of conservatories and master schools were not very interested in educational activities, choosing a solo career or becoming members of orchestras and ensembles instead. ${ }^{17}$

With regard to the educational activities of the Mariánské Hory school, two main lines can be seen which differed in content and the target group of pupils/students for whom the study was intended. Marhula focused the first (amateur) line on the music education of children and young people, and the second line on the specialised professional education of organists and music teachers. ${ }^{18}$ Right from the early days of the school in 1907 Marhula recognised that "the lack of professionally trained music professionals working in rural towns and culturally underdeveloped places results in a significant decline in care of the search for and education of musical talents and of the development of people's musical tradition". ${ }^{19}$

The period of the First World War brought considerable difficulties at the organ school, as a military sanatorium was established there, with only one room available for violin and organ classes. The teachers had to teach piano classes in their private spaces, ${ }^{20}$ and later the organ classes had to be interrupted, because Eduard Marhula and Antonín Hradil, who taught the largest number of classes in the organ department, were conscripted. The stifling atmosphere of the war period is illustrated by the text of the annual report: "The music school is deserted. Gabriel Decker teaches here in the violin department alone, also deputising the principal in his office." $" 1$

During the difficult war period, however, the Mariánské Hory school also devoted time to disabled musicians, for whom it organised three-month courses. The first course started on 1 April 1917 and the second on 1 October 1917. Their content was focused on music theory and practical instrument playing. In a sense, the organisation of three-month courses can be seen as a humanitarian gesture by the teachers of the Mariánské Hory school to "morally strengthen the unfortunate victims of the hardships of war". ${ }^{22}$

In the 1919/1920 school year, the school again had its classrooms available to the previous extent, also significantly expanding the teaching staff. In the 1920s, there was a significant qualitative development of the school, as it was expanded to include a music education department (in the 1920/1921 school year, with Rudolf Wünsch appointed as administrator). ${ }^{23}$ An article in Moravskoslezsky denik states that "the Ministry of Education and National Enlightenment has approved the establishment of a higher department for the education of organists and choir teachers, bandleaders [...] with 4 years, after the completion of which and after

17 HRADIL, Hudebníci a pěvci v kraji Leoše Janáčka, op. cit., pp. 102-103.

18 Ibid., p. 102.

19 HRADIL, Hudební tradice v kraji Leoše Janáčka, op. cit., pp. 12-13.

20 AMO, XX. jubilejni výročni zpráva 1907-1927, Moravská Ostrava, 1927, p. 10.

21 Ibid., p. 10.

22 Ibid., p. 10. KUSÁK, Z dějin regionální hudební výchovy v Ostravě v letech 1890-1918, op. cit., p. 6.

23 AMO, 40. jubilejni výročni zpráva Masarykova městského ústavu hudby a zpěvu s právem veřejnosti v Ostravě, op. cit., p. 14. HRADIL, Hudebníci a pěvci v kraji Leoše Janáča, op. cit., p. 103. An analogy can also be seen at the Music School of the Záboj Society in Slezská Ostrava: after the First World War, the school was also expanded to include a music education department thanks to Edvard Rund. For more details, see STEINMETZ - MAZUREK - KUSÁK, op. cit., p. 58. 
the school-leaving examination the students obtain valid certificates of competence for the specified profession. The curriculum follows that of state conservatories." 24 In parallel with the four-year study programme, bandleaders and organists from smaller rural municipalities could also take a one-year course. ${ }^{25}$ In 1922 , the school moved to a new building with ten classrooms (with classes being ceremoniously started on 15 October 1922). ${ }^{26}$

The statement of high-quality educational and artistic activities of the Music and Organ School in Ostrava-Mariánské Hory is also supported by contacts with leading Czech composers. In the Smetana year of 1924, Leoš Janáček visited the Mariánské Hory school to attend a lecture by F. M. Hradil, who said that he later received a letter from Janáček, characteristic of his way of expression: "Dear friend! So many students of my lectures quote my words inappropriately. I see that they have not thought them through, throwing them like children throw stones. You are an exception; that makes me happy. [...] Yours faithfully, Leoš Janáček. "²7

On 3 October 1924, Josef Bohuslav Foerster visited the Mariánské Hory school and, on that occasion, praised its quality, also supporting the students of the organ and music education departments. ${ }^{28}$ In addition to Foerster's reflection, there is also Leoš Janáček's letter dated 12 February 1925, reprinted in the annual report for the 1924/1925 school year, which contains thanks given to the school management, teachers and the school's Board of Trustees for congratulating him on his graduation from Masaryk University with a doctor of philosophy degree: "Dear Sirs! Given that you signed the address in concord, I give you all my heartfelt thanks. You can read the following in my memoirs: Grow from within, do not give up your beliefs, do not strive for recognition, but always contribute your talent to make the field destined for you to flourish. Farewell! Yours faithfully, Dr. ph. Leoš Janáček. "29

During the 1920s, the staff was largely stable. The teachers of the Music and Organ School of the Association of Education in Ostrava-Mariánské Hory included Eduard Marhula (1907-1925), Antonín Hradil (1913-1937), František Míta Hradil (1919-1947), Gabriel Decker (1909-1927), Raymond Pukovec (1921-1937) and Julius Remeš (1925-1947). ${ }^{30}$

On 6 May 1925, however, Eduard Marhula, school principal, died unexpectedly, and the aforementioned František Míta Hradil was appointed to replace him. ${ }^{31}$ In the annual report, F. M. Hradil recalls Eduard Marhula, the first principal of the school, teacher and musician, and his contribution to Ostrava's music education and Ostrava's musical life as

24 Moravskoslezský denik, 4 September 1920.

25 Ibid, p. 5.

26 AMO, 40. jubilejni výročni zpráva Masarykova městského ústavu hudby a zpěvu s právem veřejnosti v Ostravě, op. cit., p. 14. HRADIL, Hudebníci a pěvci v kraji Leoše Janáčka, op. cit., p. 103.

27 HRADIL, Hudební tradice v kraji Leoše Janáčka, op. cit., p. 11.

28 AMO, XVIII. výročni zpráva Hudebni školy Matice Školské v Mar. Horách-Mor. Ostravě za školni rok 1924-25. Mariánské Hory-Moravská Ostrava, 1925, p. 5, call number A-2650, inventory number 3129.

29 Ibid., p. 5. A transcript of the text of the letter from the annual report is also given by HRADIL, Hudebnici a pěvci v kraji Leoše Janáčka, op. cit., p. 285, and MAZUREK, op. cit., p. 245.

30 AMO, 40. jubilejni výročni zpráva Masarykova městského ústavu hudby a zpěvu s právem veřejnosti v Ostravě, op. cit., p. 20. Other teachers included Jan Kühn (1925-1927), Jan Pešat (1919-1920, 1922-1923), Josef Schreiber (1920-1921), Rudolf Vašek (1920-1921), Rudolf Wünsch (1920-1924) and Václav Lýsek (1920-1934). Ibid., p. 20.

31 He was not finally appointed principal until 9 February 1927, by a resolution of the committee of the Association of Education. 
follows: "On the occasion of the twentieth anniversary of the founding and existence of our institute, one must gratefully remember the creator of this beautiful idea and an avid fighter for its happy destiny - Eduard Marhula. [...] His merits for the flourishing of Ostrava's musical life need not be mentioned at all - they are permanent [...] As in life, Ed. Marhula was also forthright in his profession and in his art - he taught, organised and composed. [...] His compositional work is not extensive, but it is a true reflection of his feelings. [...] His healthy musicality was rooted in folk tone and folk music." 32

In his development of the school, F. M. Hradil followed Marhula's original concept, revising the curriculum, updating the study requirements and trying to comprehensively improve the teaching staff's school and extracurricular activities. He considered the school institution to be important both at educational and cultural levels and to be the artistic centre of musical events. "To be an institution of true artistic education, independent of the passing taste of a certain part of today's audience; to form a necessary element of the musical life of the same educational significance as theatre and concert [...]." ${ }^{\prime 33}$ We consider an important moment to be, for example, the use of the music school pupils as players in amateur orchestral ensembles such as the Vítkovice Orchestral Ensemble, in which Jan Pešat held the position of conductor.

Through innovations and respect for developmental continuity, F. M. Hradil contributed to the creation of a modern type of professional music education. The annual report of the Music School of the Association of Education in Mariánské Hory-Moravská Ostrava for the 1924/1925 school year outlines the organisation of the school, which consisted of a higher and lower professional school. The higher professional school consisted of an organ department and a music education department (four-year study programme); the lower professional school was divided into a violin department and an instrumental department (all string and wind instruments, eight-year study programme), a piano department (eight-year study programme), a solo, concert and opera singing department (five-year study programme), a choir singing department (six-semester study programme) and an intonation department (four-semester study programme). Study in the violin, instrumental and piano departments was divided into a preparatory school (two years), a training school (four years) and a concert playing school (two years). ${ }^{34}$

The teaching objectives are later documented in the 1928 Music Yearbook: technique and interpretation training in the fields of solo and orchestral instruments and solo and choral singing; providing a complete education qualifying the student to perform the role of organist and choir director; music teacher education; providing all pupils with a comprehensive and general music education, complemented by knowledge of science and fine arts; education of people as a means of disseminating and developing the art of music. ${ }^{35}$ The instruction was divided into theoretical and practical parts, with complementary

32 AMO, XX. jubilejni výročni zpráva 1907-1927, op. cit., pp. 8-9.

33 AMO, 40. jubilejni výročni zpráva Masarykova městského ústavu hudby a zpěvu s právem veřejnosti v Ostravě, op. cit., p. 15.

34 AMO, XVIII. výročni zpráva Hudebni školy Matice Školskév var. Horách-Mor. Ostravě za školní rok 1924-25, op. cit., p. 8.

35 POKOJ, O. Hudebni ročenka na rok 1928. Brno, 1928, p. 118. 
forms of music education, namely courses for organists, choirmasters and bandleaders, nursery teachers and preparation for school-leaving examinations at teacher training institutes. Lecture courses were focused on selected chapters of musical aesthetics. ${ }^{36}$ Regarding the organ department, we should mention that the school management supported the pupils in working as auxiliary organists, choirmasters and bandleaders in Ostrava and the surrounding area, for example, in Polanka, Poruba, Radvanice, Třebovice, Karviná and Vítkovice. ${ }^{37}$

On 23 May 1925, shortly after Marhula's death, an official inspection was carried out by Antonín Hromádka, state inspector for music schools. He learnt how teaching was done at the music school and provided the teachers with other valuable professional advice to increase the artistic and educational level of the institute. Regular professional meetings of the Mariánské Hory teachers led to the innovation of the curriculum with new didactic and methodological knowledge and the inclusion of new musical compositions that appeared at the time.

A preparatory department that focused on the musical development of preschool children was also established within the music school to apply elements of Émile Jaques-Dalcroze's rhythmics education. ${ }^{38}$ From the mid-1930s, the teaching of rhythmics was mainly connected with Josefa Tylová, who had previous experience with it from working with Dobromila, a women's charity association under whose auspices she founded (after she had come to Ostrava in 1929) rhythmics courses, hitherto unknown to the public in Ostrava. ${ }^{39} \mathrm{~A}$ mention of the issue of rhythmics education and its importance within music education can be found in the daily press of the late 1930s: "[...] Dalcroze's method is still fresh, modified in our country by our elements of national songs, which makes it so close to us. In Switzerland, the cradle of Dalcroze's school, various types of nerve and brain diseases are treated with rhythm. And if rhythm works for sick people, what great results of both physical and mental harmony can be achieved with rhythm in healthy people, again especially children!" 40

The school offered those interested the opportunity for further self-education by reading the professional music press, such as Helfert's Hudebni rozhledy, Listy Hudebni matice, Hudebni výchova and Blecha's journal Za hudebnim vzdèlánim; pupils in lower years were recommended the journal Hudebni besidka mládeže.$^{41}$ The possibility for pupils to meet prominent personalities of both concert and scientific life can also be considered a signifi-

36 Ibid., p. 119.

37 AMO, XX. jubilejni výročni zpráva 1907-1927, op. cit., p. 20.

38 In the context of the development of interwar music education, Émile Jaques-Dalcroze's method can be considered very inspiring and modern. In April 1936, the Society for Music Education held the first international congress in Prague, during which a number of important issues in music education (music sociology, music psychology, etc.) were discussed. The congress was attended by important personalities, such as the aforementioned Émile Jaques-Dalcroze. For more details on modernisation of interwar music education, see KUSÁK, Jiří MAZUREK, Jan. Modernizační tendence v meziválečné české hudební výchově (1918-1938). Hudebni výchova. 2020, Vol. 28, No. 4, pp. 6-10.

39 TYLEČEK, B. Sedmnáct let učitelkou rytmiky. Výchova k hudebnosti a pružnosti. České Slovo, 4 June 1942.

40 -a-. Dětem rytmika. Moravskoslezský denik, 26 March 1939.

41 AMO, XX. jubilejni výročni zpráva 1907-1927, op. cit., p. 20; see also STEINMETZ - MAZUREK - KUSÁK, op. cit., p. 58, and MAZUREK, op. cit., p. 246. 
cant contribution of the Mariánské Hory school. At the end of the 1920s (on the occasion of a concert in Ostrava), at the invitation of the school management, the school was visited by the violinist Ervína Prokešová (31 March 1927) and Jan Heřman (28 April 1927); at the end of the 1930s (28 March 1938), students could attend a lecture by Gracian Černušák, organised by the Circle of Friends of Classical Music. In his lecture, Černušák focused on the development of choral singing, including the development of forms, explanation of notation, performance practice and conducting. The lecture was complemented by numerous interesting recordings - gramophone records ${ }^{42}$ and choral demonstrations. ${ }^{43}$

In addition to educational activities, the school management also emphasised awareness-raising activities leading to the expansion of knowledge and skills through attending concerts, theatre (especially opera) performances and music lectures not held on the institute premises. For example, in the 1926/1927 school year, pupils became acquainted with important music ensembles that performed in Ostrava, such as the Moravian Quartet and Rosé Quartet, the Singing Ensemble of Moravian Teachers (conductor V. Vach), the Czech Philharmonic (conductor V. Talich), the Philharmonic Ensemble in Moravská Ostrava (conductor J. Pešat) and the Orchestral Ensemble in Moravská Ostrava (conductor A. Aich). Pupils also saw some of the most famous operas: Aida (G. Verdi), A Masked Ball (G. Verdi), Dalibor (B. Smetana), Eugene Onegin (P. I. Tchaikovsky), Madame Butterfly (G. Puccini), Rusalka (A. Dvořák), The Tales of Hoffmann (J. Offenbach), The Flying Dutchman (R. Wagner), etc. ${ }^{44}$

Due to the concentrated music education of people in the Ostrava region and adjacent Silesia and especially the considerable interest in studying at Hradil's school, branches were established in the early 1930s in other Ostrava districts, namely in Přívoz (in the Catholic People's House), Zábřeh nad Odrou (in a boys' primary school) and Svinov in Silesia (in a lower secondary school). "It can be expected that the establishment of these branches will substantially stimulate an interest in professional music education." 45 In 1931, there was a significant innovation in the music education department, as a training music school was established. ${ }^{46}$ Observations and teaching practice took place in the classes of erudite teachers, which led to an increase in knowledge and skills in educational practice. The establishment of a training music school, the inclusion of observations and teaching practice can therefore be assessed from the point of view of music education and didactics as a modernising element not only in the context of development of the school itself, but also of Czech interwar music education in general.

The outlined trends and a wide range of artistic activities of Hradil's school had a positive influence on interest in studying at the local institution, but from the early 1930s it

42 It should be noted that the gramophone was an innovative material and didactic tool in the music education of the interwar period, especially in the 1930s.

43 Invitation to a lecture by G. Černušák dated 28 March 1938. AMO, "Základní umělecká škola Ostrava-Moravská Ostrava, ul. Sokolská, Ostrava-Moravská Ostrava” collection, inventory number 1, chronicle of the Masaryk Institute of Music and Singing.

44 AMO, XX. jubilejni výročni zpráva 1907-1927, op. cit., pp. 19-20.

45 AMO, XXIV. výročni zpráva 1930-1931. Moravská Ostrava-Mariánské Hory, 1931, p. 4.

46 HRADIL, Hudebníci a pěvci v kraji Leoše Janácka, op. cit., s. 103-104. 
was clear that the school's capacity was insufficient and that a more spacious building (in the centre of Moravská Ostrava) would have to be found. The Association of Education and the Lumír singing society managed to buy a building in Moravská Ostrava. ${ }^{47}$ On 28 September 1935, the grand opening of the new school building took place, with the school activities continuing under the new name - the Masaryk Institute of Music and Singing. ${ }^{48}$ "The largest professional music institute in Moravska Ostrava is the Masaryk Institute of Music and Singing, which, in addition to educating music professionals, pays special attention particularly to the musical education of children and young people in general. [...] It seeks to ensure that the need for music education permeates all classes of the nation [...]." $" 4$

From the very beginning of the transformation of the Mariánské Hory school into the Masaryk Institute of Music and Singing, a significant expansion of the organ department was planned; ${ }^{50}$ a considerable development of the institute (including the expansion of the teaching staff $)^{51}$ can also be read in the daily press of that time, which reported that the institute fulfilled both educational and cultural needs very successfully and was a school institution sought after by students from the greater Ostrava region, Těšín region, Frýdek region, Opava region, and even Slovakia! "The interest and popularity enjoyed by the Masaryk Institute of Music and Singing in Silesia, Northeast Moravia and adjacent Slovakia attracts numerous students to come here in order to pursue professional music education. ${ }^{52}$

The teachers at the Masaryk Institute of Music and Singing also carried out a wide range of artistic activities. We consider this beneficial, because they could effectively use the experience in their methodological work with their pupils, which thus gained important support in interpretation practice: for example, Josef Bartl worked as a guest conductor of the Radiojournal Orchestra in Moravská Ostrava from September to December 1937; Emil Mikelka was a soloist with Radiojournal in Moravská Ostrava from October to December 1937 (performing compositions including those by Leoš Janáček: In the Mists, Piano Sonata 1.X.1905 - From the Street), and, on 22 February 1938, performed at the 2nd

47 STEINMETZ, - MAZUREK, - KUSÁK, op. cit., p. 58. JUDr. Rudolf Matouš, whose merits can be seen in the development of Czech singers and its promotion (initiation of memoranda, intercessions with influential people, concluding negotiations with the Copyright Protection Association, etc.). For more details, see TUREČEK, Jaroslav. Památce bratra starosty JUDra Rudolfa Matouše. Věstnik pěvecký a hudebni, Vol. XLIII, No. 5, 15 May 1939, pp. 67-68. For more details on Rudolf Matouš, see also the article "Dr. Matouš - 70 Jahre". Ostrauer Zeitung: Abendblatt, 3 February 1938.

48 Moravskoslezský denik, 30 September 1935; České Slovo, 1 October 1935.

49 um-x. Hudební výchova mládeže na Ostravsku. Hudba a zpěv, neodlučitelná složka obecné výchovy. Národní politika, 18 April 1939.

50 The Masaryk Institute of Music and Singing had a total of eighteen rooms in the central building in Moravská Ostrava (at No. 20 Hviezdoslavova), a branch for school pupils in the lowest years in the previous building in Mariánské Hory and also a branch in Nový Jičín.

51 From the 1930s, the teachers working at the Masaryk Institute of Music and Singing included Josef Bartl (1935-1939), Anna Černíková-Stračovská (1937-1940), Norbert Dörfler (1937-1941), Ludmila Mašková (19361937) and Josefa Tylová (1936-1946). AMO, 40. jubilejni výročni zpráva Masarykova městského ústavu hudby a zpěvu s právem veřejnosti v Ostravě, op. cit., p. 20.

52 -ba-. Kultura-divadlo-film. České Slovo, 10 June 1938. 
concert of the 11th symphonic cycle (conducted by Jaroslav Vogel);53 on 26 October 1937, Anna Černíková-Stračovská interpreted Vítězslav Novák’s Songs Based on Moravian Folk Poetry with Radiojournal in Moravská Ostrava. ${ }^{54}$

In addition to artistic activities, there is also mention of lectures and music-organisational activities by some of the institute teachers. In the 1931/1932-1933/1934 seasons, the Cultural Council for the Greater Ostrava Region organised three series of music lectures entitled Composers about Themselves, in which František Míta Hradil participated as one of the organisers. ${ }^{55}$ The public in Ostrava could also become acquainted with leading contemporary composers who talked about their lives and compositions. Ostrava hosted Jaroslav Křička, Karel Boleslav Jirák, Vilém Petrželka, Osvald Chlubna, Boleslav Vomáčka, Jaroslav Kvapil, Václav Kaprál, Alois Hába, Vojtěch Bořivoj Aim and Jan Kunc. ${ }^{56}$ These activities were a unique way of popularising music, because the public in Ostrava had the opportunity to obtain relevant information about the musical arts from the actual composers, not indirectly, and the lecture series aimed to bring culture to the Ostrava population. In addition to interpretation, there were excerpts from selected compositions by the aforementioned composers which were performed by (among other artists) the teachers at the Mariánské Hory school, such as F. M. Hradil, Julius Remeš, as well as Norbert Dörfler, later a teacher at the Masaryk Institute of Music and Singing (from 1937). Another active lecturer was Josefa Tylová, who spoke about orthopaedics in Brno on 7 December 1937 (at the invitation of the Association of Rhythmic Dance and Gymnastics Teachers) and who led a two-month course in physical education and rhythmics organised by nursery teachers in Moravská Ostrava. ${ }^{57}$

At the end of the 1930s, the Masaryk Institute of Music and Singing was an educational institution of high quality, ${ }^{58}$ with artistic significance and results reaching a level comparable to music conservatoires. ${ }^{59}$ "It is known that great progress has been made in Ostrava by promoting music. Ostrava is now one of the important centres of musical life in the republic, gaining

53 jš. Druhý symfonický koncert ostravský, Lidové noviny, 26 February 1938. -ba-. Symfonický koncert. České Slovo, 24 February 1938. M. B. XI. Symfonický cyklus. Moravskoslezský denık, 24 February 1938. Ostrauer Zeitung, 23 February 1938.

54 AMO, "Základní umělecká škola Ostrava-Moravská Ostrava, ul. Sokolská, Ostrava-Moravská Ostrava" collection, inventory number 1 , chronicle of the Masaryk Institute of Music and Singing.

55 The main contributors to the promotion of the lecture series were František Míta Hradil, Milan Balcar and Jan Pešat, who critically reported on the course and content of the lectures in the periodical daily press - Černá země, Duch času and Morauskoslezský denik.

56 For more details, see KUSÁK, Jiř́i. Hudební lidovýchovné aktivity v Ostravě v období od 20. do 40. let 20. století. In Janáckiana 2014. Sbornik z 32. ročniku muzikologické konference Janáckiana 2014. Ostrava: Ostravská univerzita v Ostravě, Pedagogická fakulta, 2015, pp. 215-221. KUSÁK, Jiří. Hudební popularizační aktivity v Ostravě v letech 1931-1934. Teoretické reflexe hudebni výchovy. 2015, No. 2, pp. 24-29. STEINMETZ - MAZUREK - KUSÁK, op. cit., p. 58, and MAZUREK, Jan. Hudební skladatelé o sobě (Př́íspěvek Kulturní rady pro širší Ostravsko hudební kultivaci obyvatel regionu). In Česká hudebni pedagogika a vzděláváni dospèlých na počátku 21. století. Sbornik z 28. muzikologické konference Janáckiana. Praha: Divadelní ústav, 2006, pp. 26-34.

57 AMO, "Základní umělecká škola Ostrava-Moravská Ostrava, ul. Sokolská, Ostrava-Moravská Ostrava" collection, inventory number 1 , chronicle of the Masaryk Institute of Music and Singing.

58 dj. Hudební školství v Moravské Ostravě. Lidové noviny, 29 June 1939.

59 -ba-. Kultura-divadlo-film. České Slovo, 10 June 1938. 
more and more friends. Therefore, there should be a music conservatoire in Ostrava which would complement the high level of music education in the Ostrava region. This could also be achieved by the Ministry of Education renaming the Masaryk Institute of Music and Singing to the Conservatoire of Music." 60

"Since its humble beginnings, the former Music School of the Association of Education has developed into today's widely organised institute, at the forefront of Czech music education." 61

During the Protectorate period, ${ }^{62}$ the institute carried out a wide range of activities, albeit with certain restrictions, and the institute ${ }^{63}$ was not fully open again until after the end of the Second World War.

\section{Internal and public performances, "style" evenings, music celebrations, competitions (contests), concerts and dance productions}

A significant problem in the analysis and interpretation of the artistic activities of the Music and Organ School of the Association of Education in Ostrava-Mariánské Hory is the absence of relevant archival documents about the events held from the establishment of the school in 1907 to the 1920s. However, it can be assumed that even in that period numerous artistic activities organised by the Music and Organ School took place.

Internal and public school performances were of great importance from the point of view of music education, because students were led to present the compositions they had learnt in front of a wider audience. For example, in the 1924/1925 school year, a total of five performances were held, with violin, piano, chamber and orchestral compositions. The individual performances were preceded by an introductory speech by F. M. Hradil, particularly on music education of people. ${ }^{64}$ In the 1930/1931 school year, seven external performances ${ }^{65}$ three Soloist Evenings, ${ }^{66}$ one Matinée of Sacred Music ${ }^{67}$ and eleven "style" evenings took place! Based on a detailed study of the performance programmes, it can be generalised that they regularly included compositions from the standard repertoire (Boccherini, Tchaikovsky, Drdla, Dvořák, Fibich, Grieg, Haydn, Chopin, Křička, Mozart, Novák,

60 V. P. Hudební konservatoř v Ostravě. České Slovo, 1938. The article without an exact date is published for 1938 in the chronicle of the Masaryk Institute of Music and Singing; AMO, "Základní umělecká škola Ostrava-Moravská Ostrava, ul. Sokolská, Ostrava-Moravská Ostrava” collection, inventory number 1.

61 České Slovo, 25 June 1939.

62 For more details, see KUSÁK, Odborná hudební výchova v Ostravě v období Protektorátu Čechy a Morava, op. cit., pp. 253-262.

63 In the Protectorate period, the name was changed to the Institute of Music and Singing.

64 Hudba v dětské duši, O našich skladatelich, O cílech hudebni školy, Škola literni a škola hudebni, O lidovýchovném významu hudby. AMO, XVIII. výročni zpráva Hudebni Školy Matice Školské v Mar. Horách-Mor. Ostravě za školni rok 1924-1925, op. cit., pp. 4-5.

65 On 17 November, 16 December and 18 December 1930, and 17 February, 21 April, 2 June and 22 June 1931.

66 On 3 June, 17 June and 26 June 1931.

67 On 11 June 1931 in the parish church in Mariánské Hory. 
Rieding, Sarauer, Schumann, Suk, etc.), but also compositions by less known or less played composers (J. B. Accolay, J. Blatný, F. Bridge, A. Gretchaninov, J. Hrušková, A. Huber, E. Köhler, F. Kovařík, A. Löschhorn, R. Ráček, J. Skalický, O. Šín, etc.). The pupils from the rhythmics department also had the opportunity to perform at the performances. ${ }^{68}$

When the institute's style evenings were organised, speeches by F. M. Hradil were also included in the overall concept, with the task to prepare the audience for the following programme from the point of view of music theory, music history and music aesthetics or to pursue the goals of general education of people (special attention was paid to contemporary music) ${ }^{69}$ The style evenings held in the 1930/1931 school year (including the related speeches) can be thematically divided into several areas: 1 . composer personalities - A Fibich Evening (19 December 1930, with the speech "The Creative Phenomenon of Fibich”), A Novák Evening (23 February 1931, with the speech “To Vítězslav Novák on His Sixtieth Birthday"); 2. music for children and young people - An Evening of Compositions for Young People (1 June 1931); ${ }^{70}$ 3. contemporary music - The 1st Evening of Contemporary Music (5 June 1931, with the speech "How to Listen to Contemporary Music"), The 2nd Evening of Contemporary Music (12 June 1931, with the speech "Along the Paths of Contemporary Music"); 4. music of a certain musical style - An Evening of Romantics (6 June 1931, with the speech "Music Education in a Music School"); 5. music of European nations - An Evening of Czech Music (8 June 1931, with the speech "The Ideological Essence of Contemporary Czech Music”), An Evening of French Music (15 June 1931, with the speech "The Artistic Idea of French Music"); 6. artificial and folk song - An Evening of Songs and Arias (10 June 1931, with the speech "From the History of Artificial Song"), An Evening of Czechoslovak Folk Song (19 June 1931, with the speech "The Importance of Folk Song in National Culture”); 7. music for a selected musical instrument - An Evening of Violin Compositions (9 June 1931). ${ }^{71}$

The music productions included music celebrations to mark current anniversaries the birthday of President T. G. Masaryk (7 March 1927), ${ }^{72}$ the birthday of the poet Petr Bezruč (17 November 1937)..$^{73}$ The celebratory music productions were also aimed at commemorating the anniversaries of composers; for example, in 1927 it was the centenary of the death of Ludwig van Beethoven, whose jubilee was reflected in a series of lectures and concert evenings. As part of the programme, F. M. Hradil prepared a series of three lectures on Beethoven's life and work, supplemented with analyses and reproductions (23 February, 2 March and 9 March 1927). The celebrations of Beethoven's artistic legacy culminated in a Beethoven exhibition which was originally to take place from 26 to 31 March

68 AMO, "Základní umělecká škola Ostrava-Moravská Ostrava, ul. Sokolská, Ostrava-Moravská Ostrava” collection, inventory number 1 , chronicle of the Masaryk Institute of Music and Singing.

69 AMO, XXIV. výročni zpráva 1930-1931, op. cit., pp. 11-12.

70 The style evening was probably not preceded by a speech (there is no mention of one).

71 The evening was probably not preceded by a speech either (there is no mention of one).

72 The pupils performed at the President's 77th birthday celebration as part of the school matinée during which selected vocal compositions, compositions for mixed choir and recitations were performed.

73 AMO, “Základní umělecká škola Ostrava-Moravská Ostrava, ul. Sokolská, Ostrava-Moravská Ostrava” collection, inventory number 1, chronicle of the Masaryk Institute of Music and Singing. 
1927 in the House of Arts in Moravská Ostrava. However, for technical reasons, Principal F. M. Hradil obtained permission to publicly present the rich exhibition material on the premises of the Mariánské Hory school. In addition to these celebrations of the Beethoven jubilee, the pupils of the Mariánské Hory school also took part in all Beethoven evenings organised by other Ostrava institutions. ${ }^{74}$

The Masaryk Institute of Music and Singing was also involved in organising music competitions. From 14 to 19 June 1937, to mark the 30th anniversary of its existence, the institute organised music and singing competitions, which more than sixty people took part in. ${ }^{75}$ These competitions were in the following disciplines: piano playing, violin playing and solo singing at intermediate and higher levels. The jury was composed of leading artists from the Ostrava region was chaired by F. M. Hradil. The competitions were also attended by Dr. Ludvík Kundera, state inspector for music and a teacher at the State Conservatoire in Brno, Gustav Pivoňka, Director of the Žerotína Music School in Olomouc, and other representatives of the boards of trustees and teachers from music schools in Prostějov, Olomouc, Karviná, Petřvald, Frýdek and Radvanice, as well as numerous private music teachers. The institute's chronicle contains the information that the first prize in the piano playing category (intermediate level) was awarded to Ilja Hurník. ${ }^{76}$

Another significant contribution to culture in Ostrava was made by the orchestra of the Masaryk Institute of Music and Singing and a mixed choir. On 7 April 1938, the Lumír singing society from Moravská Ostrava organised a concert in the National House. The programme included Haydn's The Storm, a cantata for mixed choir and orchestra. ${ }^{77}$ A reflection published in the daily press states that "an ensemble of about 130 members successfully managed to perform the undemanding singing parts of Haydn's composition. A much more extensive task was to be conducted by the orchestra, the core of which was formed by the orchestra of the Masaryk Institute, but very much strengthened by other musicians, especially from the ranks of the Ostrava Radio Orchestra" ${ }^{78}$

Other numerous important concerts in the period under study included the Piano Evening held on 3 May 1938, which took place as part of public performances by pupils within the Young People Play and Sing series, "in which the Masaryk Institute of Music and Singing demonstrates not only the extraordinary values of its artistic education [...]". ${ }^{79}$ Piano compositions by significant composers were performed, for example Chopin, Liszt, Smetana, etc. At the piano evening, the aforementioned Ilja Hurník (at that time a pupil of the

74 AMO, XX. jubilejni výročni zpráva 1907-1927, op. cit., p. 14.

75 Lidové noviny, 2 July 1937.

76 AMO, "Základní umělecká škola Ostrava-Moravská Ostrava, ul. Sokolská, Ostrava-Moravská Ostrava” collection, inventory number 1, chronicle of the Masaryk Institute of Music and Singing. Another competition was held by the institute on 20 May 1939 and was focused on the best performance in playing technical exercises. The pupils from the piano classes led by Principal F. M. Hradil and E. Mikelka, as well as from the violin class led by J. Remeš took part in the competition. Ibid.

77 The mixed choir was composed of members of the Lumír singing society, the student choir of the Masaryk Institute of Music and Singing, and the Karlova Hut' u Lískovce singing society (the concert was conducted by Josef Bartl).

78 Moravskoslezský denik, 9 April 1938.

79 -ba-. Klavírní večer. České Slovo, 8 May 1938. 
Masaryk Institute of Music and Singing) also performed his own composition entitled Fantasie-toccata. This clearly shows that the institute's teachers supported their pupils not only in terms of interpretation, but also in composition, creating space for them to present their personality in art more comprehensively.

In Moravskoslezsky denik, Milan Balcar wrote positively about the successful educational guidance of the institute's pupils: "If we hear Neighbour's Dance from Smetana's Czech Dances or the whole of Suk's Spring at the end of a performance of any school's piano department, very satisfactory both in both technical and interpretation terms, we must say that such a result could only be achieved where remarkable talent was led by a fully educationally qualified hand. [...] Another very interesting component of Tuesday evening was Hurnik's Fantasie-toccata, which the young, but already well-known Ostrava composer played brilliantly, having in his composition, very free-running in terms of both form and expression, a full opportunity to apply his very early emerged artistic abilities. With regard to composition, he is Principal Hradil's pupil." 80 The reflection in České Slovo emphasises the technical complexity of Hurník's composition, which "even in its formal freedom shows all the characteristics of extraordinary musical talent". ${ }^{81}$

F. M. Hradil commented on the issue of composing music in a later interview published in the daily press, in which he pointed out that music education involves the pupil's personal talent and that in professional music education, especially for children, individualisation is a very important factor in teaching a musical instrument. The teachers often encouraged students to express themselves independently - that is, to create their own pieces of music. ${ }^{82}$

On 10 May 1938, the Evening of Violin Compositions took place (as the 4th evening of the Young People Play and Sing series), ${ }^{83}$ with gifted pupils from the violin class led by J. Remeš performing. Remeš's educational qualities, supported by his own artistic activity, are evidenced by a laudatory review in the daily press. The review in České Slovo noticed the extraordinary talent and technical skills of E. Kunisch, aged just eleven, in Tartini's Sonata in G Minor: "He already shows much style and understanding, his soft tone revealing taste and musicality. " 84

The artistic activities developed at the Masaryk Institute of Music and Singing also included dance productions, which were devised by Josefa Tylová and her pupils. For example, during a concert evening on 17 May 1938, her pupils gave expressive performances based on music by Dalcroze, Grieg, Beethoven, Smetana, Weiss and others. Milan Balcar wrote the following in his review: "Smetana's Polka in E Flat Major, whose rhythmic freshness and melodic charm were in good agreement with the performance and appearance of J. Šumavská, followed by Weiss's South Bohemian Songs, in which a group of six well-dancing girls had impressive support for their performance in their tasteful costumes, which made all the better

80 BALCAR, Milan. Vstup do období závěrečných produkcí hudebních škol. Moravskoslezský denik, 5 May 1938 , p. 4.

81 -ba-. Klavírní večer. České Slovo, 8 May 1938.

82 RUML, V. Hudební výchova mládeže na Ostravsku. Hudební kultura - budoucnost národní hudební tvorby. Moravskoslezský denik, 16 April 1939.

83 For information on the event, see the article "Dva zajímavé večery v Mor. Ostravě”. České Slovo, 8 May 1938.

84 -ba. Večer houslových skladeb Masarykova ústavu. České Slovo, 15 May 1938. 
effect as the fabric curtains and special lighting provided the front of the hall of the House of Arts with the appearance of a scene. "\$5

The quality of dance teaching at the institute (already at the beginning of the Protectorate period) can be seen in the pupils' artistic work beyond Ostrava. For example, a student of the Masaryk Institute of Music and Singing (Jitřenka Šumovská) organised an Evening of Artistic Dance in the People's House hall in Luhačovice. "The evening, attended by high society from all over Bohemia and Moravia, [...] not only contributed to the cultural, artistic and social revival of the spa season, but also clearly demonstrated that Ostrava does not want to be left behind other cities in artistic dance." 86

\section{Conclusion}

The educational and artistic activities of the Music and Organ School of the Association of Education in Ostrava-Mariánské Hory / Masaryk Institute of Music and Singing can be summarised in several partial conclusions. The school was one of the first institutions established under the auspices of societies or associations in Ostrava, and during the period under study its organ and music education departments were of fundamental importance. The school's concept, reputation (confirmed by authorities such as Leoš Janáček and Josef Bohuslav Foerster) and achievements in music education testify to the high quality of the institution.

The development of the school institution was directly and positively influenced particularly by Eduard Marhula and František Míta Hradil, as well as by other teachers, such as Josef Bartl, Antonín Hradil, Emil Mikelka and Julius Remeš. Some teachers were also active as concert artists, especially in the Ostrava context, which allowed them to functionally apply methodological and didactic procedures supported by real artistic practice in their teaching activities. The high-quality music education work was manifested in the organisation of a large number of artistic events, ${ }^{87}$ reflections on which can be found in the press of that time. The artistic events were continuously supplemented by the pupils' other cultural and educational activities.

85 BALCAR, Milan. Masarykův ústav hudby a zpěvu. Moravskoslezský denik, 20 May 1938. The pupils from the rhythmics class led by Josefa Tylová also presented their skills a year later - in the Protectorate period - as part of the Concert Evening held on 25 May 1939. -x. Večer rytmického uměleckého tance v Mor. Ostravě. Národni politika, 31 May 1939.

86 JP-. Večer tanečního mládí. Úspěšný večer mladičké Ostravanky v Luhačovicích. České Slovo, 30 July 1939.

87 The article "Hudební výchova na Ostravsku" (without further specification) in the chronicle of the Masaryk Institute of Music and Singing, AMO, “Základní umělecká škola Ostrava-Moravská Ostrava, ul. Sokolská, Ostrava-Moravská Ostrava” collection, inventory number 1, states that from the establishment of the Mariánské Hory school until the 1936/1937 school year a total of 504 public concerts put on by pupils and teachers took place! 


\section{Bibliography}

České Slovo (1935, 1938, 1939).

Dalibor (1900, 1901, 1904).

Lidové noviny (1937).

Morauskoslezský denik (1920, 1935, 1938).

Opauský týdennik (1895-1896).

Ostravský dennik (1910, 1914, 1916-1917).

Ostravský kraj (1910, 1912-1917).

Ostrauer Zeitung (1893-1897, 1899, 1902-1903, 1905-1907, 1923, 1925-1926, 1931, 1935, 1938).

Poledni ostrauský denik (1929).

-a-. Dětem rytmika. Moravskoslezský denik, 26 March 1939.

-ba-. Klavírní večer. České Slovo, 8 May 1938.

-ba-. Kultura-divadlo-film. České Slovo, 10 June 1938.

-ba-. Symfonický koncert. České Slovo, 24 February 1938.

-ba. Večer houslových skladeb Masarykova ústavu. České Slovo, 15 May 1938.

Archiv města Ostravy (AMO), "Základní umělecká škola Ostrava-Moravská Ostrava, ul. Sokolská, Ostrava-Moravská Ostrava” collection, inventory number 1, chronicle of the Masaryk Institute of Music and Singing.

AMO, XVIII. výročni zpráva Hudebni školy Matice Školské v Mar. Horách-Mor. Ostravě za školni rok 1924-25. Mariánské Hory-Moravská Ostrava, 1925, call number A-2650, inventory number 3129 .

AMO, XIX. výroční zpráva 1925-1926. Mariánské Hory-Moravská Ostrava, 1926, call number A-2650, inventory number 3129.

AMO, XX. jubilejni výročni zpráva 1907-1927. Moravská Ostrava, 1927, call number A-2650, inventory number 3129.

AMO, XXIV. výročni zpráva 1930-1931. Moravská Ostrava-Mariánské hory, 1931, call number A-2650, inventory number 3129.

AMO, 40. jubilejni výročni zpráva Masarykova městského ústavu hudby a zpěvu s právem veřejnosti v Ostravě. Ostrava, 1947, call number A-2651/1, inventory number 3130.

BALCAR, Milan. Masarykův ústav hudby a zpěvu. Moravskoslezský denik, 20 May 1938.

BALCAR, Milan. Vstup do období závěrečných produkcí hudebních škol. Moravskoslezský denik, 5 May 1938.

dj. Hudební školství v Moravské Ostravě. Lidové noviny, 29 June 1939.

Dr. Matouš - 70 Jahre. Ostrauer Zeitung: Abendblatt, 3 February 1938.

Dva zajímavé večery v Mor. Ostravě. České Slovo, 8 May 1938.

JP-. Večer tanečního mládí. Úspěšný večer mladičké Ostravanky v Luhačovicích. České Slovo, 30 July 1939.

jš. Druhý symfonický koncert ostravský. Lidové noviny, 26 February 1938.

M. B. XI. symfonický cyklus. Moravskoslezský denik, 24 February 1938.

RUML, V. Hudební výchova mládeže na Ostravsku. Hudební kultura - budoucnost národní hudební tvorby. Moravskoslezský denik, 16 April 1939.

TUREČEK, Jaroslav. Památce bratra starosty JUDra Rudolfa Matouše. Věstnik pěvecký a hudebni, Vol. XLIII, č. 5, 15 May 1939, pp. 67-68.

TYLEČEK, B. Sedmnáct let učitelkou rytmiky. Výchova k hudebnosti a pružnosti. České Slovo, 4 June 1942. 
um-x. Hudební výchova mládeže na Ostravsku. Hudba a zpěv, neodlučitelná složka obecné výchovy. Národní politika, 18 April 1939.

-x. Večer rytmického uměleckého tance v Mor. Ostravě. Národni politika, 31 May 1939.

V. P. Hudební konservatoř v Ostravě. České Slovo, 1938 (without further date).

GREGOR, Vladimír. Československá společnost pro hudebni výchovu (1934-1938) a mezinárodni dosah jeji činnosti. 1st ed. Praha: SPN, 1974.

GREGOR, Vladimír - SEDLICKÝ, Tibor. Dějiny hudebni výchovy v českých zemích a na Slovensku. 1st ed. Praha: Supraphon, 1973.

HRADIL, František Míta. Hudebníci a pěvci v kraji Leoše Janáčka. Paměti a dokumentace. 1st ed. Ostrava: Profil, 1981.

HRADIL, František Míta. Hudební tradice v kraji Leoše Janáčka. K 60. výročí trvání lidové školy umění v Ostravě 1. In: 60 let lidové školy v Ostravě. Ostrava, 1967, pp. 5-14.

KADLEČEK, Rudolf. O výchově hudebni. Popularisace myšlenky o správné výchově hudebni. Moravská Ostrava, 1905.

KADLEČEK, Rudolf. Theorie hmatniku houslového Př́ručni knižka ku vyučováni počátkưm hry na houslích pro učitele i žáka. Moravská Ostrava, 1904.

KÖNNEMANN, Arthur. Rascher zum Ziel. Anleitung zur höheren technischen Ausbildung der Hand auf mechanischem Wege. Moravská Ostrava, 1892.

KUSÁK, Jiří. Akademická hudební škola v letech 1891-1917. Hudebni výchova. 2016, Vol. 24, No. 4, pp. 4-6. ISSN 1210-3683.

KUSÁK, Jiří. Didactic-Analytical and Content-Related Reflection on the Works by Ostrava Teachers Rudolf Kadleček and Arthur Könnemann in the Context of Specialized Music Education in the Early 20th Century. In: Horizonty umenia 6. Banská Bystrica: Akadémia umení v Banskej Bystrici, Fakulta múzických umení, 2019, pp. 230-240.

KUSÁK, Jiří. Hudební lidovýchovné aktivity v Ostravě v období od 20. do 40. let 20. století. In Janáčkiana 2014. Sbornik z 32. ročniku muzikologické konference Janáčkiana 2014. Ostrava: Ostravská univerzita v Ostravě, Pedagogická fakulta, 2015, pp. 215-221.

KUSÁK, Jiří. Hudební popularizační aktivity v Ostravě v letech 1931-1934. Teoretické reflexe hudebni výchovy. 2015, No. 2, pp. 24-29.

KUSÁK, Jiří. Hudební výchova v meziválečné Ostravě. Muzikologické fórum. 2016, No. 1, pp. 45-54.

KUSÁK, Jiří. Music Education in Ostrava in Protectorate of Bohemia and Moravia (1939-1945). Aura musica. 2015, No. 7, pp. 12-19.

KUSÁK, Jiří. Music Education of Ostrava Germans from the 1890's to 1930's. Musik-Bildungs-Anstalt (1893-1931). In: Mezhkul'turnoye vzaimodeystviye v sovremennom muzykal'no-obrazovatel'nom prostranstve. Moskva: Moskovskiy gosudarstvennyy institut kul'tury, Kafedra muzykal'nogo obrazovaniya, 2017, pp. 357-363.

KUSÁK, Jiří Odborná hudební výchova v Ostravě v období Protektorátu Čechy a Morava. In: Janáčkiana 2016. Sbornik z 33. ročníku muzikologické konference Janáckiana 2016. Ostrava: Ostravská univerzita, Pedagogická fakulta, 2017, pp. 253-262.

KUSÁK, Jiří. Ostrava hudebněvýchovná. Hudebni výchova, odborná hudebni výchova, hudebni výchova $v$ učitelské př́pravě, hudebni lidovýchovné a popularizačni aktivity v Ostravě od 90. let 19. století do roku 1945. Ústí nad Labem, 2017, 302 pages. Habilitation Thesis. Univerzita Jana Evangelisty Purkyně v Ústí nad Labem, Pedagogická fakulta.

KUSÁK, Jiří. K počátkům odborné hudební výchovy v Ostravě od 90. let 19. století na příkladu Akademické hudební školy (1891-1917) Rudolfa Kadlečka. In: Horizonty umenia 3. Zbornik 
z vedeckej webovej konferencie s mezinárodnou účastou. Banská Bystrica: Akadémia umení v Banskej Bystrici, 2015, pp. 151-158.

KUSÁK, Jiří. Z dějin regionální hudební výchovy v Ostravě v letech 1890-1918. Odborná hudební výchova. Hudebni výchova. 2016, Vol. 24, No. 1-2, pp. 4-7.

KUSÁK, Jiří - MAZUREK, Jan. Modernizační tendence v meziválečné české hudební výchově (1918-1938). Hudebni výchova. 2020, Vol. 28, No. 4, pp. 6-10.

MAZUREK, Jan. Hudební skladatelé o sobě (Příspěvek Kulturní rady pro širší Ostravsko hudební kultivaci obyvatel regionu). In Česká hudebni pedagogika a vzdèláváni dospělých na počátku 21. století. Sbornik z 28. muzikologické konference Janáckiana. Praha: Divadelní ústav, 2006, pp. 26-34.

MAZUREK, Jan. Hudebni život českých obyvatel Ostravy v obdobi 1880-1918. Spisy Ostravské univerzity, No. 119. 1st ed. Ostrava: Ostravská univerzita v Ostravě, Pedagogická fakulta, 1999.

MAZUREK, Jan. K dějinám Hudební a varhanické školy Matice školské v Ostravě-Mariánských Horách (1907-1935). Hudebni nástroje. 1995, No. 4, pp. 245-246.

MAZUREK, Jan - KUSÁK, Jiří - ADÁMKOVÁ, Hana. Hudba meziválečného období (1918-1938). In MAZUREK, Jan - STEINMETZ, Karel - ADÁMKOVÁ, Hana et al. Ostravská hudebni kultura od konce 19. století do současnosti. 1st ed. Ostrava: Ostravská univerzita v Ostravě, Pedagogická fakulta, 2010, pp. 39-76.

POKOJ, O. Hudebni ročenka na rok 1928. Brno, 1928.

STEINMETZ, Karel - MAZUREK, Jan - KUBEŠOVÁ, Hana. Kapitoly z historie německé hudební kultury v Ostravě 1860-1945. Osobnosti, instituce, reflexe. 1st ed. Ostrava: Ostravská univerzita v Ostravě, Pedagogická fakulta, 2013.

STEINMETZ, Karel - MAZUREK, Jan - KUSÁK, Jiří et al. Ostrava hudebni. Vývoj hudebni kultury jednoho města v poslednich 160 letech. 1st ed. Ostrava: Ostravská univerzita v Ostravě, Pedagogická fakulta, 2014. 
